\title{
Surgical treatment of refractory incontinence in the bitch
}

\author{
Chirurgische behandeling van refractaire incontinentie bij de teef
}

\author{
J. Timmermans, B. Van Goethem, H. de Rooster
}

Small Animal Teaching Hospital, Faculty of Veterinary Medicine, Ghent University, Salisburylaan 133, 9820 Merelbeke, Belgium

bart.vangoethem@ugent.be

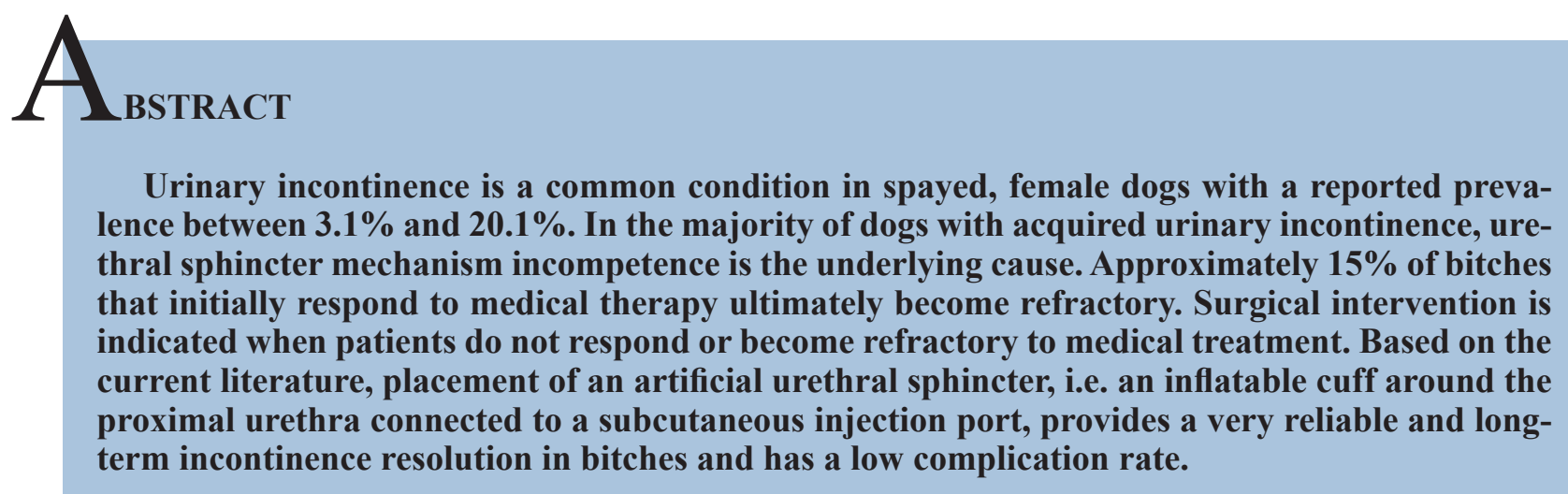

\section{SAMENVATTING}

Urinaire incontinentie is een vaak voorkomende aandoening bij gesteriliseerde teven met een gerapporteerde prevalentie tussen $3,1 \%$ en $20,1 \%$. Bij de meeste honden met verworven urinaire incontinentie is er sprake van een onderliggende urethrale sfinctermechanisme-incompetentie. Ongeveer $15 \%$ van de teven die initieel verbeteren met medicamenteuze behandeling, wordt uiteindelijk refractair. Chirurgische interventie is aangeraden wanneer patiënten niet verbeteren ondanks medicamenteuze behandeling of refractair worden aan medicamenteuze behandeling. Gebaseerd op de huidige literatuur biedt de plaatsing van een artificiële urethrale sfincter, dit is een opblaasbare "cuff" rondom de proximale urethra die verbonden is met een subcutane injectiepoort, een zeer betrouwbare en langdurige oplossing voor incontinentie bij teven, waarbij zelden complicaties optreden.

\section{INTRODUCTION}

In spayed, female dogs, urinary incontinence (UI) is a common condition with a reported prevalence between 3.1 and 20.1\% (Arnold et al., 1989; O'Neill et al., 2017). The majority of dogs with acquired UI suffer from urethral sphincter mechanism incompetence (USMI) (Byron et al., 2017). The first treatment option in dogs affected by acquired UI is medical management. Although some cases become refractory to treatment, medical management is highly efficient in many cases. (Applegate et al., 2018). Urinary incontinence and subsequent medical management have been discussed in more detail in a previous literature review article published in this journal (Timmermans et al., 2019).
Historically, different surgical options have been researched. In this review, indications for surgical treatment in patients with acquired UI due to USMI are highlighted and the currently available surgical options are discussed.

\section{SURGICAL TREATMENT}

Surgical treatment is indicated 1 . when patients do not respond to medical treatment or encounter severe adverse effects from it, 2 . to treat refractory urinary incontinence, or 3. when owners are reluctant to administer lifelong medication. A large number of dogs with USMI are eventually presented as candidates for surgical treatment, since approximately $15-20 \%$ of 


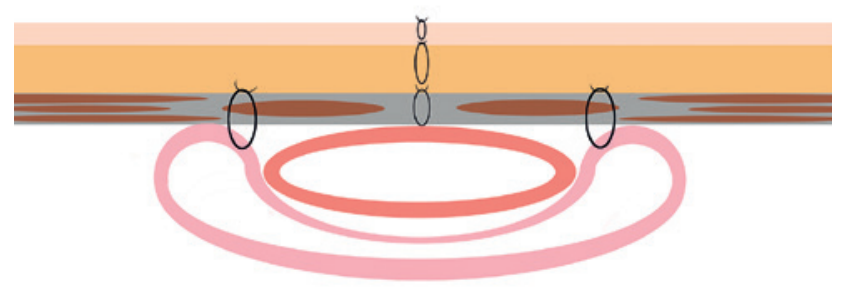

Figure 1. Schematic representation of the colposuspension technique illustrating how the vaginopexy (pink) compresses the urethra (orange) to the abdominal wall (grey).

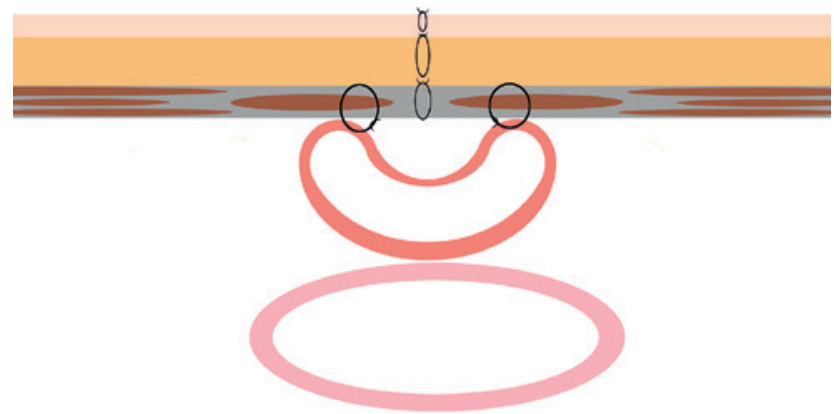

Figure 2. Schematic representation of the urethropexy technique illustrating how the procedure is reducing the diameter of the urethral lumen (orange). bitches that initially respond to medical therapy ultimately become refractory (Scott et al., 2002; Adin, 2014). Additionally, until recently, most surgical procedures could not provide long-term continence; however, technological advances seem to have eliminated this problem.

\section{Colposuspension}

Colposuspension is essentially a vaginopexy that entraps the urethra between the vagina and the abdominal wall using nonabsorbable, monofilament suture material (Mcloughlin and Chew, 2009; Claeys et al., 2010b). Increased external compression of the proximal urethra is caused both by the compressive effect from the vaginopexy and also by the repositioning of both the bladder neck and proximal urethra into a more cranial intra-abdominal position (Rawlings et al., 2001; Applegate et al., 2018) (Figure 1).

Short-term continence is achieved in approximately $55 \%$ of cases. However, in a study by Rawlings et al. (2001), continence decreased to $14 \%$ one year postoperatively $(\mathrm{n}=23 \mathrm{dogs})$. Additional medical therapy resulted in regained continence in a total of $38 \%$ of dogs after one year (Rawlings et al., 2001) (Table 1).

Major complications, including (partial) urethral obstruction, are rare (Rawlings et al., 2001; Mcloughlin and Chew, 2009). Transient dysuria is the most commonly observed minor complication.

Table 1. Data summary of surgical treatment options of refractory incontinence other than the artificial urethral sphincter.

\begin{tabular}{|c|c|c|c|c|c|c|c|c|c|}
\hline & \multirow[t]{2}{*}{$\mathbf{n}$} & \multirow[t]{2}{*}{$\begin{array}{l}\text { Follow-up } \\
\text { (months) }\end{array}$} & \multicolumn{2}{|c|}{$\begin{array}{l}\text { Short-term } \\
\text { continence }\end{array}$} & \multicolumn{2}{|c|}{$\begin{array}{l}\text { Long-term } \\
\text { continence }\end{array}$} & \multicolumn{2}{|c|}{$\begin{array}{l}\text { Compli- } \\
\text { cations }\end{array}$} & \multirow{2}{*}{$\begin{array}{l}\text { Owner } \\
\text { satis- } \\
\text { faction }\end{array}$} \\
\hline & & & SX & SX + MED & SX & SX + MED & Minor & Major & \\
\hline \multicolumn{10}{|l|}{ Colposuspension } \\
\hline Rawlings et al. (2001) & 23 & 12 & $55 \%$ & N/A & $14 \%$ & $38 \%$ & N/A & N/A & $83 \%$ \\
\hline \multicolumn{10}{|l|}{ Urethro(cysto)pexy } \\
\hline Massat et al. (1993) & 10 & 14 & N/A & $40 \%$ & $10 \%$ & $30 \%$ & $20 \%$ & 0 & $60 \%$ \\
\hline White (2001) & 100 & 54 & $\mathrm{~N} / \mathrm{A}$ & $\mathrm{N} / \mathrm{A}$ & $56 \%{ }^{\dagger}$ & - & $20 \%$ & $3 \%$ & $77 \%$ \\
\hline \multicolumn{10}{|l|}{ Urethropexy and colposuspension } \\
\hline Martinoli et al. (2014) & 30 & 39 & N/A & N/A & $70 \%$ & N/A & $10 \%$ & 0 & $97 \%$ \\
\hline \multicolumn{10}{|l|}{ Urethral bulking } \\
\hline Barth et al. (2005) & 40 & 12 & $68 \%$ & $83 \%$ & $28 \%$ & $65 \%$ & $15 \%$ & 0 & $70 \%$ \\
\hline Bartges and Callens (2011) & 22 & 1 & $77 \%$ & - & $\mathrm{N} / \mathrm{A}$ & $\mathrm{N} / \mathrm{A}$ & $18 \%$ & 0 & N/A \\
\hline Byron et al. (2011) & $21^{*}$ & 56 & N/A & N/A & N/A & N/A & N/A & N/A & N/A \\
\hline \multicolumn{10}{|l|}{ Transobturator vaginal tape } \\
\hline Claeys et al. (2010) & 7 & 11 & $71 \%$ & $85 \%$ & $71 \%$ & $85 \%$ & $14 \%$ & 0 & $85 \%$ \\
\hline Deschamps and Roux (2015) & 12 & 48 & $92 \%$ & N/A & $25 \%$ & - & $58 \%$ & $25 \%$ & $83 \%$ \\
\hline Hamon et al. (2019) & 12 & 85 & $83 \%$ & - & $40 \%$ & $80 \%$ & $17 \%$ & 0 & $80 \%$ \\
\hline
\end{tabular}

Short-term continence $<6$ months; long-term continence $>6$ months, SX: surgery, SX + MED: surgery and medication, N/A: data not available in the publication, *Study on a total of 31 dogs of which 21 patients with USMI, $\uparrow 40$ out of 100 dogs were excluded from long-term analysis, $\$ 2$ out of 12 dogs were excluded from long-term analysis. 


\section{Urethro(cysto)pexy}

Urethropexy consists of attaching the urethra to the ventral abdominal wall whereas with cystourethropexy, both the urethra and the bladder are attached to the abdominal wall (Mcloughlin and Chew, 2009). Nonabsorbable monofilament sutures are used in these techniques (Mcloughlin and Chew, 2009). During both procedures, the bladder neck and proximal urethra are repositioned more cranially in the abdomen. When performing a urethropexy, the diameter of the urethral lumen is reduced, creating higher urinary flow resistance (Massat et al., 1993; Mcloughlin and Chew, 2009) (Figure 2).

A prospective study on urethropexy performed by White (2001) revealed $87 \%$ short-term improvement $(\mathrm{n}=100 \mathrm{dogs})$. However, long-term continence decreased to $56 \%$ approximately three years postoperatively (Table 1). Unfortunately, the effects of additional medical treatment following a urethropexy were not evaluated in the study by White (2001). Results after cystourethropexy are less positive than the urethropexy results, with only $10 \%$ continence after surgery and 30\% long-term continence when phenylpropanolamine was administered $(\mathrm{n}=10 \mathrm{dogs})$ (Massat et al., 1993).

Major complications are rare, with 3\% of affected dogs requiring revision surgery due to anuria or avulsion of the urethropexy site (White, 2001; Martinoli et al., 2014). Minor complications are common, occurring in $20 \%$ of affected dogs, and include transient pollakiuria and dysuria.

Martinoli et al. (2014) described the combination of urethropexy and colposuspension in female dogs with refractory UI $(n=30 \mathrm{dogs})$ and found higher success rates compared to the rates found when either of these techniques were used alone. In that study, the combination therapy achieved long-term continence in $70 \%$ of dogs after a median follow-up of approximately 39 months. Complications were mild and temporary in $10 \%$ of cases. Remarkably, combining these two techniques is likely to decrease the risk of avulsion; this combination has been successful in bitches with previous avulsion of the soft tissues (Martinoli et al., 2014).

\section{Urethral bulking}

Urethral bulking is a minimally invasive treatment method where bulking agents are injected into the urethral submucosa (Arnold et al., 1996). Under videoendoscopic guidance, the bulking agents are injected in the proximal urethra at the 2-, 6-, and 10-o'clock positions to increase the urethral closure pressure (Klarskov and Lose, 2008; Byron et al., 2011; Applegate et al., 2018) (Figure 3). Bovine glutaraldehyde crosslinked collagen used to be the gold standard (Bartges and Callens, 2011; Byron et al., 2011), but is no longer available on the European market (Lüttmann et

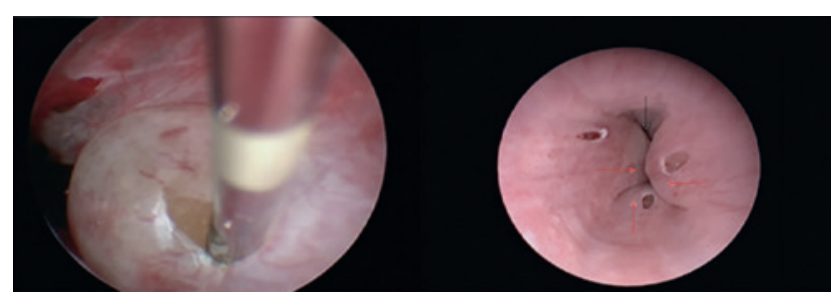

Figure 3. Videoendoscopic view of urethral bulking during (left) and after (right) injection of bulking agents (From: Applegate et al., 2018).

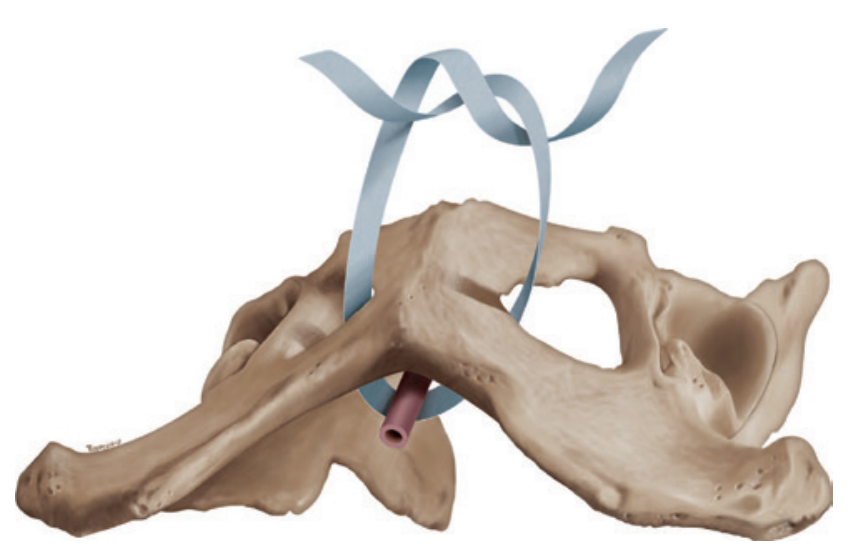

Figure 4. Schematic representation illustrating the placement of the transobturator vaginal tape using the inside-out variant (From: Deschamps and Roux, 2015).

al., 2019). In a study by Bartges and Callens (2011), polydimethylsiloxane was used as an alternative. In that study, 22 female dogs, of which $77 \%$ were continent, were included; there was a follow-up period of only one month (Bartges and Callens, 2011). Recent$1 y$, continence results after endoscopic urethral injections of dextranomer/hyaluronic acid copolymer have been reported by Lüttmann et al. (2019). Their findings identified the new copolymer as a valuable substitution. However, it provided a shorter duration of continence than bovine glutaraldehyde cross-linked collagen (Lüttmann et al., 2019).

Efficacy of solo-treatment with urethral injections is approximately $60-70 \%$, but rises to $83 \%$ when dogs simultaneously receive alpha-adrenergic agonists, such as phenylpropanolamine (Barth et al., 2005; Byron et al., 2011) (Table 1). Over time, migration and flattening of the material in the mucosa occur, leading to a $40 \%$-decrease in efficacy after one year of injecting collagen and the recurrence of UI $(n=40$ dogs $)$ (Barth et al., 2005). To assure life-long continence, repeated injections are required (Byron et al., 2011).

No major complications, meaning patients requiring revision surgery, have been reported. Minor complications, usually of transient nature, occur in approximately $15 \%$ of patients that underwent urethral bulking and include stranguria, hematuria, and vaginitis (Barth et al., 2005; Lüttmann et al., 2019). 
Table 2. Published results of the surgical treatment of refractory incontinence with an artificial urethral sphincter.

$\begin{array}{lccccccccc} & & \text { n } & \begin{array}{c}\text { Follow-up } \\ \text { (months) }\end{array} & \begin{array}{c}\text { Short-term } \\ \text { continence }\end{array} & \begin{array}{c}\text { Long-terme } \\ \text { continence }\end{array} & \begin{array}{c}\text { AUS } \\ \text { cuff } \\ \text { inflation }\end{array} & \begin{array}{c}\text { Complications } \\ \text { cations }\end{array} & \begin{array}{c}\text { Owner } \\ \text { satis- } \\ \text { faction }\end{array} \\ & & & & & & & & & \end{array}$

Short-term continence: $<6$ months; long-term continence: $>6$ months, SX: surgery, SX + MED: surgery and medication, N/A: data not available in the publication, M: male dogs. Only data from female dogs was evaluated when possible.

\section{Transobturator vaginal tape}

The technique was first described in women by Cho et al. (2011). Its most recent modification, the transobturator vaginal tape inside-out variant, is currently used in veterinary medicine (Claeys et al., 2010a; Hamon et al., 2019) (Figure 4). A polypropylene tape is applied around the distal third of the urethra using a specific needle and polyethylene tubes as a guide (Claeys et al., 2010a). The exact mechanism of action remains unclear, but increased periurethral tension due to the foreign body or an inflammatory response induced by the device might be the reason for regaining continence (Hamon et al., 2019).

In a study by Claeys et al. (2010a) including seven dogs, a complete continence was observed in $86 \%$ of patients after a mean follow-up of eleven months (Claeys et al., 2010a) (Table 1). Although Deschamps and Roux (2015) reported a complete urinary continence in eleven out of twelve dogs $(92 \%)$ within two weeks after surgery, long-term results revealed complete long-term continence in only $25 \%$ of the dogs and an additional $25 \%$ of patients with major improvement at a median follow-up of four years. In a more recent study by Hamon et al. (2019), more positive results were reported, with complete continence in four out of ten dogs at a median follow-up of seven years $(\mathrm{n}=12 \mathrm{dogs})$. However, two dogs in that study were excluded from the long-term analysis due to factors outside of the study's control. Additional medical treatment consisted of phenylpropanolamine, oestrogen or a combination of both. Due to this additional treatment, the continence rates of four out of the six remaining dogs that were not responding to solo treatment, improved (Hamon et al., 2019).

In a study by Deschamps and Roux (2015), major complications, such as fistula formation, occurred in three out of twelve dogs $(25 \%)$ and required implant removal; however these complications did not occur in the two other studies (Claeys et al., 2010; Hamon et al., 2019). Minor complications occurred in 14$58 \%$ of patients and included transient dysuria and an iatrogenic urethral tear (Claeys et al., 2010; Deschamps and Roux, 2015; Hamon et al., 2019).

\section{Artificial urethral sphincter}

The artificial urethral sphincter (AUS) consists of an inflatable silicone cuff placed around the urethra that is connected to a subcutaneous access port (Adin et al., 2004) (Figure 5). The device is available in different sizes depending on the diameter of the urethra, which is measured either preoperatively via ultrasonographic examination or intraoperatively.

Tapered cuff inflation with sterile saline, adapted to the individual patient, is a unique advantage compared to other surgical techniques. In approximately $25-50 \%$ of patients, continence is regained due to the semi-rigid structure of the cuff and the more intraabdominal position of the bladder (Rose et al., 2009). However, in dogs that remain incontinent four to six weeks postoperatively, inflation of the silicone cuff with $0.1-0.2 \mathrm{ml}$ increments is performed (Reeves et al., 2013). According to a cadaveric study performed by Adin et al. (2004), the minimum volume to obtain complete occlusion of the lumen of the AUS cuff is $0.4 \mathrm{ml}$. Interestingly, recent studies show that higher total cuff inflation volumes of up to $2 \mathrm{ml}$ might be required to achieve continence and can be tolerated by patients without adverse effects (Gomes et al., 2018; Morgan et al., 2018). In the event of side effects, such as stranguria or pollakiuria, the cuff can easily be deflated via the subcutaneous access port (Rose et al., 2009; Delisser et al., 2012; Currao et al., 2013; Gomes et al., 2018; Morgan et al., 2018).

Long-term continence rates in the literature vary between 28-100\% (Rose et al., 2009; Delisser et al., 2012; Currao et al., 2013; Gomes et al., 2018; Morgan et al., 2018) (Table 2). When interpreting these results and comparing them with other surgical techniques, it is important to note that dogs with major improvement are not included in the continence rates. Delisser et al. (2012) for example found that $36 \%$ of the eleven dogs in their study were completely continent at the end of 
the study. However, the median continence score of all dogs in that study was 9/10 (range, 7/10-10/10). In a recent study by Gomes et al. (2018) with a follow-up of three years (range: $365-2.257$ days), $40 \%$ of complete continence and another $50 \%$ with major improvement $(n=20$ dogs $)$ were shown. In other studies, similar continence scores have been reported (Delisser et al., 2012; Currao et al., 2013; Gomes et al., 2018; Morgan et al., 2018) and scores at two weeks, three and six months were 8 (4 to 10). Another important factor in the evaluation of the results of the AUS system is the owner compliance (Currao et al., 2013). Final continence results may be lower due to owners deeming the situation clinically manageable and declining further follow-up visits to fill the cuff until full continence is achieved (Reichler et al., 2006; Currao et al., 2013; Byron, 2015). Currao et al. (2013) reported a long-term complete continence rate of $56 \%$ in dogs approximately 2.5 years after placement, which increased to $77 \%$ in cases with compliant owners allowing continued cuff inflations (Table 2).

Additional medical therapy should be considered when patients have recurrence of incontinence and have the cuff filled. Previous reports show a lot of variation in the need for additional medication, from 0-61\% (Delisser et al., 2012; Currao et al., 2013). The
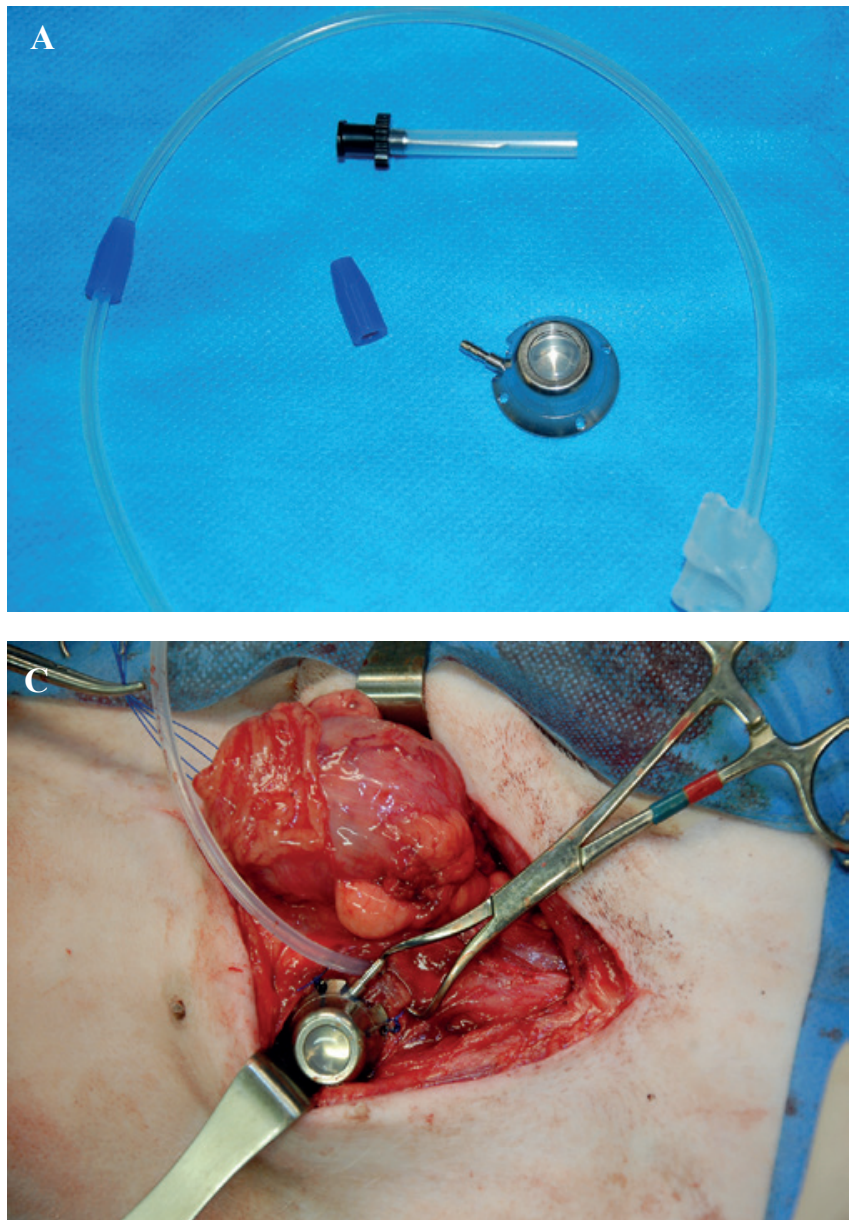

infrequent requirement of medical therapy after AUS placement is likely a result of the semi-rigid structure of the cuff, as mentioned by Rose et al. (2009).

Major complications, including urethral obstruction, urethral stricture, urethral laceration, implant failure by cuff leakage, or implant infection have been reported in $0-17 \%$ of cases (Rose et al., 2009; Delisser et al., 2012; Currao et al., 2013; Reeves et al., 2013; Gomes et al., 2018; Morgan et al., 2018). Treatment consists of device removal (Currao et al., 2013). Minor complications are common (Delisser et al., 2012) and include dysuria, seroma formation and pain originating from the subcutaneous port. These complications are either transient or can be resolved with medications such as non-steroidals. Other minor complications such as stanguria require cuff deflation (Rose et al., 2009; Delisser et al., 2012; Currao et al., 2013; Reeves et al., 2013).

\section{CONCLUSION}

Evaluation of the current literature shows that there is a large disparity between results. Comparison is therefore not always accurate. The AUS system provides the best long-term results for the surgi-
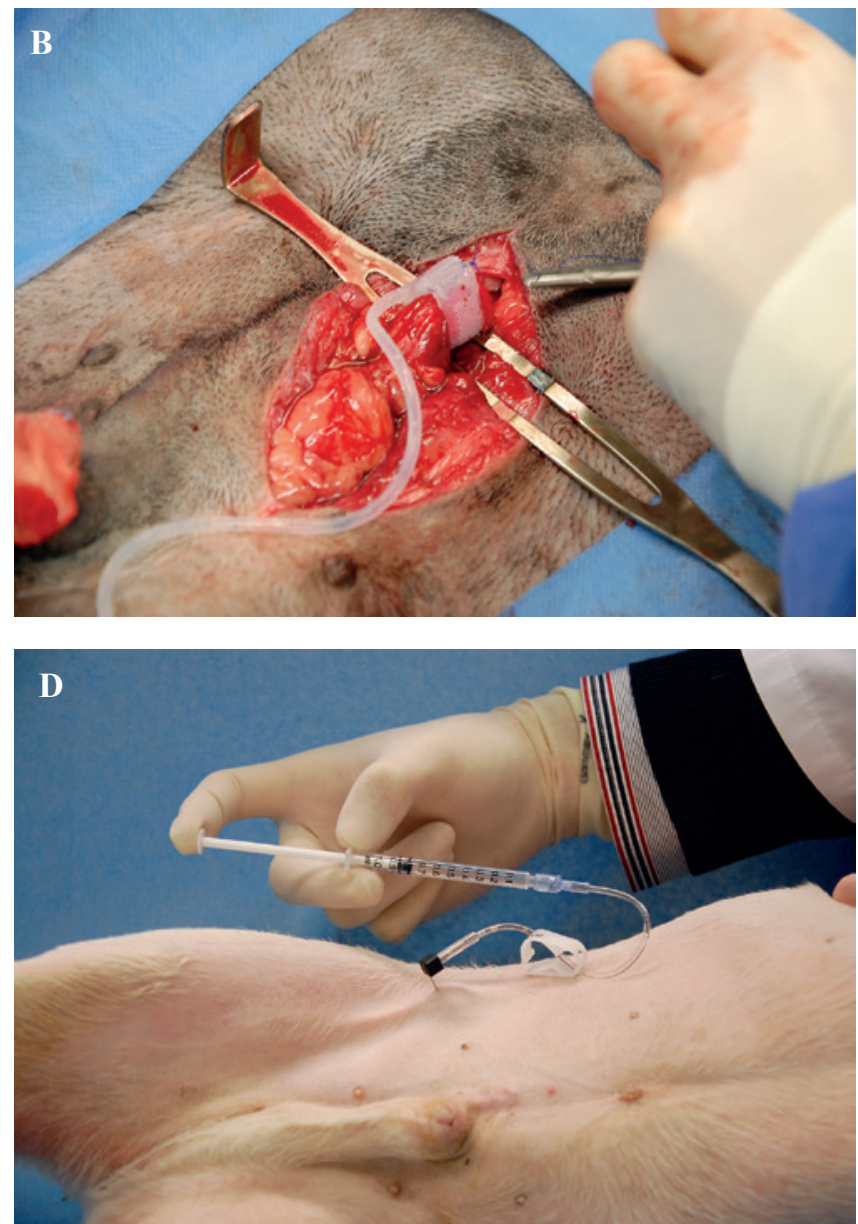

Figure 5. Placement of an AUS. A. An overview of the individual components. B. The inflatable cuff is placed around the urethra distal to the trigone. $C$. The subcutaneous access port is placed in a subcutaneous pocket lateral to the mammary chain. D. Postoperative filling of the cuff with sterile saline using a dedicated needle. 
cal treatment of bitches with refractory UI, with most dogs achieving full continence. Cuff inflation allows individualized tapering until complete continence occurs, although only $55-75 \%$ of patients will require inflation to achieve complete urinary continence. For dogs that do not achieve full continence, supplementary medical therapy can further improve the continence rates.

\section{REFERENCES}

Adin, C.A., Farese, J.P., Cross, A.R., Provitola, M.K., Davidson, J.S., Jankunas, H., (2004). Urodynamic effects of a percutaneously controlled static hydraulic urethral sphincter in canine cadavers. American Journal of Veterinary Research 65, 283-288.

Applegate, R., Olin, S., Sabatino, B., (2018). Urethral sphincter mechanism incompetence in dogs: an update. Journal of the American Animal Hospital Association 54, 22-29.

Arnold, S., Arnold, P., Hubler, M., Casal, M., Rüsch, P., (1989). Urinary incontinence in spayed female dogs: frequency and breed disposition. Schweizer Archiv für Tierheilkunde 131, 259-263.

Arnold, S., Hubler, M., Lott-Stolz, G., Rüsch, P., (1996). Treatment of urinary incontinence in bitches by endoscopic injection of glutaraldehyde cross-linked collagen. Journal of Small Animal Practice 37, 163-168.

Bartges, J., Callens, A., (2011). Polydimethylsiloxane urethral bulking agent (pdms uba) injection for treatment of female canine urinary incontinence - preliminary results. In: Proceedings of the annual Veterinary Medical Forum - American College of Veterinary Internal Medicine 2, 748-749.

Barth, A., Reichler, I.M., Hubler, M., Hässig, M., Arnold, S., (2005). Evaluation of long-term effects of endoscopic injection of collagen into the urethral submucosa for treatment of urethral sphincter incompetence in female dogs: 40 cases (1993-2000). Journal of the American Veterinary Medical Association 226, 73-76.

Byron, J.K., 2015. Micturition disorders. Veterinary Clinics of North America - Small Animal Practice 45, 769-782.

Byron, J.K., Chew, D.J., Mcloughlin, M.L., (2011). Retrospective evaluation of urethral bovine cross-linked collagen implantation for treatment of urinary incontinence in female dogs. Journal of Veterinary Internal Medicine 25, 980-984.

Byron, J.K., Taylor, K.H., Phillips, G.S., Stahl, M.S., (2017). urethral sphincter mechanism incompetence in 163 neutered female dogs: diagnosis, treatment, and relationship of weight and age at neuter to development of disease. Journal of Veterinary Internal Medicine 31, 442-448.

Claeys, S., De Leval, J., Hamaide, A., (2010a). Transobturator vaginal tape inside out for treatment of urethral sphincter mechanism incompetence: preliminary results in 7 female dogs. Veterinary Surgery 39, 969-979.

Claeys, S., Noël, S., Hamaide, A., (2010b). Acquired urinary incontinence in the bitch: Update and perspectives from human medicine. Veterinary Journal 186, 25-31.

Currao, R.L., Berent, A.C., Weisse, C., Fox, P., (2013). Use of a percutaneously controlled urethral hydraulic occluder for treatment of refractory urinary incontinence in 18 female dogs. Veterinary Surgery 42, 440-447.

Delisser, P.J., Friend, E.J., Chanoit, G.P.A., Parsons, K.J., (2012). Static hydraulic urethral sphincter for treatment of urethral sphincter mechanism incompetence in 11 dogs. Journal of Small Animal Practice 53, 338-343.

Deschamps, J.Y., Roux, F.A., (2015). Transobturator vaginal tape for treatment of urinary incontinence in spayed bitches. Journal of the American Animal Hospital Association 51, 85-96.

Forsee, K.M., Davis, G.J., Mouat, E.E., Salmeri, K.R., Bastian, R.P., (2013). Evaluation of the prevalence of urinary incontinence in spayed female dogs: 566 cases (20032008). Journal of the American Veterinary Medical Association 242, 959-962.

Gomes, C., Doran, I., St, D., Friend, E., Tivers, M., Chanoit, G., (2018). Long-term outcome of female dogs treated with static hydraulic urethral sphincter for urethral sphincter mechanism incompetence. Journal of the American Animal Hospital Association 54, 276-284.

Hamon, M., Hamaide, A.J., Noël, S.M., Claeys, S., (2019). Long-term outcome of the transobturator vaginal tape inside out for the treatment of urethral sphincter mechanism incompetence in female dogs. Veterinary Surgery 48, 29-34.

Klarskov, N., Lose, G., (2008). Urethral injection therapy: what is the mechanism of action? Neurourology and Urodynamics 27, 789-792.

Lüttmann, K., Merle, R., Nickel, R., (2019). Retrospective analysis after endoscopic urethral injections of glutaraldehyde-cross-linked-collagen or dextranomer/hyaluronic acid copolymer in bitches with urinary incontinence. Journal of Small Animal Practice 60, 96-101.

Martinoli, S., Nelissen, P., White, R.A.S., (2014). The outcome of combined urethropexy and colposuspension for management of bitches with urinary incontinence associated with urethral sphincter mechanism incompetence. Veterinary Surgery 43, 52-57.

Mcloughlin, M.A., Chew, D.J., (2009). Surgical treatment of urethral sphincter mechanism incompetence in female dogs. Compendium Continuing Education for Veterinarians 31, 360-373.

Morgan, K., Milner, H.R., Tikekar, A., Smith, H.L., Coomer, A.R., (2018). Long term use of hydraulic artificial urethral sphincters in nine dogs from New Zealand with urethral sphincter mechanism incompetence. New Zealand Veterinary Journal 66, 1-5.

O’Neill, D.G., Riddell, A., Church, D.B., Owen, L., Brodbelt, D.C., Hall, J.L., (2017). Urinary incontinence in bitches under primary veterinary care in England: prevalence and risk factors. Journal of Small Animal Practice 58, 685-693.

Rawlings, C., Barsanti, J.A., Mahaffey, M.B., Bement, S., (2001). Evaluation of colposuspension for treatment of incontinence in spayed female dogs. Journal of the American Veterinary Medical Association 219, 770-775.

Reeves, L., Adin, C., Mcloughlin, M., Ham, K., Chew, D., 2013. Outcome after placement of an artificial urethral sphincter in 27 dogs. Veterinary Surgery 42, 12-18.

Reichler, I.M., Jöchle, W., Piché, C.A., Roos, M., Arnold, S., (2006). Effect of a long acting GnRH analogue or placebo on plasma LH/FSH, urethral pressure profiles and clinical signs of urinary incontinence due to Sphincter mechanism incompetence in bitches. Theriogenology 66, 1227-1236.

Rose, S.A., Adin, C.A., Ellison, G.W., Sereda, C.W., Ar- 
cher, L.L., (2009). Long-term efficacy of a percutaneously adjustable hydraulic urethral sphincter for treatment of urinary incontinence in four dogs. Veterinary Surgery 38, 747-753.

Scott, L., Leddy, M., Bernay, F., Davot, J.L., (2002). Evaluation of phenylpropanolamine in the treatment of urethral sphincter mechanism incompetence in the bitch. Journal of Small Animal Practice 43, 493-496.
Timmermans, J., Van Goethem, B., De Rooster, H., Paepe, D., (2019). Medical treatment of urinary incontinence in the bitch. Vlaams Diergeneeskundig Tijdschrift 88, 3-8.

White, R.N., (2001). Urethropexy for the management of urethral sphincter mechanism incompetence in the bitch. Journal of Small Animal Practice 42, 481-486.

\section{Gynaecologie: geen geschikte term in de diergeneeskunde}

Het woord 'gynaecologie' wordt dikwijls gebruikt als synoniem voor verloskunde. Maar die tak van de (dier)geneeskunde is uiteraard veel ruimer. Dat weet iedereen. Etymologisch betekent gynaecologie kennis (Grieks: logos) over de huisvrouw (Grieks gynè: vrouw; oikos: huis). De term verraadt dat eeuwenlang enkel het geslachtsleven en de daarmee gepaard gaande ziektetoestanden van de huisvrouw - de getrouwde vrouw - voor de medische wetenschap van belang waren. 'Geestelijke (geest-gelijke) dochters', religieuzen, werden niet verondersteld een geslachtsleven te hebben en andere vrouwen waren uitschot, tenzij ze, bij voorkeur als jonge maagd, konden 'dienen' om huisvrouw te worden.

Gynaecologie: niet echt een geschikte term dus voor ... diergeneeskundig gebruik. Maar welke dan wel? 